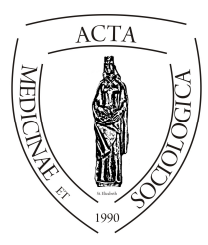

doi:

\title{
Potyázók, anómiások, rituális perzisztensek és célori- entált perzisztensek. A hallgatói lemorzsolódás szokatlan veszélyei
}

\author{
Ceglédi Tímea
}

Kutató, Debreceni Egyetem Felsőoktatási Kutató és Fejlesztő Központ (CHERD-Hungary), egyetemi tanársegéd, Debreceni Egyetem Nevelés- és Múvelődéstudományok Intézete, Cím: 4032 Debrecen, Egyetem tér 1. II/204.

\section{INFO}

\section{ABSTRACT}

Freeloaders, anomic students, ritual persistent students and goal-oriented persistent students. Unusual risks in higher educational students' dropout. The question of our

\section{Keywords}

persistence, dropout, higher education, commitment study is measuring the relationship between the risk of dropout and the belief in the usefulness of the higher educational certificate and the effort to obtain it. In our analysis, the student database of the HERD research $(\mathrm{N}=1295)$ was used. Four groups were identified by cluster analysis. 1) Among the anomic students (the group described with anomie), the level of belief the usefulness of the higher educational certificate and the effort toward that is the lowest while the risk of dropping out is the highest. 2) The ritual persistent (i.e. tenacious) students are able to make strong efforts but do not believe in the degree. Their diligence does not offer them the same level of protection against dropout as 3) the goal-oriented persistence which means that the student believes in the degree as well besides the diligence. 4) The freeloaders are less diligent, but aware of the value of the degree, offering them bigger protection than the disappointed diligence of the ritual persistent students. Among the target-oriented persistent group is higher the proportion of students who learnt in an elite secondary educational institution and who has a graduated householder, while among the ritual persistent group the proportion of those having priority admission points due to disadvantaged/cumulative disadvantaged $(\mathrm{HH} / \mathrm{HHH})$ position is higher.

\footnotetext{
Kulcsszavak perzisztencia, lemorzsolódás, felsőoktatás, iskolához való viszony
}

Absztrakt. Tanulmányunk kérdése, hogy milyen összefüggésben áll a lemorzsolódás kockázatával a diploma hasznosságába vetett hit és az annak megszerzéséért nyújtott erőfeszítés. Elemzésünkhöz a HERD kutatás hallgatói adatbázisát 


\begin{abstract}
használtuk ( $\mathrm{N}=1295)$. Klaszterelemzéssel négy csoportot azonosítottunk. 1) Az anómiások körében a legkisebb a diplomába vetett hit és az érte nyújtott erőfeszítés, s ezzel összefüggésben náluk a legmagasabb a lemorzsolódás kockázata. 2) A rituális perzisztensek (azaz kitartók) magas erőfeszítésekre képesek, de nem hisznek a diplomában. Szorgalmuk nem nyújt számukra akkora védelmet a lemorzsolódástól, mint a 3) célorientált perzisztencia, vagyis az, ha valaki szorgalma mellett hisz is a diplomában. 4) A potyázók kevésbé szorgalmasak, de tudatában vannak a diploma értékének, amely nagyobb védettséget biztosít számukra, mint a rituális perzisztensek kiábrándult szorgalma. A célorientált perzisztensek körében magas a diplomás családfövel és elit középiskolai múlttal, míg rituális társaik esetében a HH/HHH többletponttal rendelkezők aránya.
\end{abstract}

Ez a tanulmány a Társadalmi és szervezeti tényezők szerepe a hallgatói lemorzsolódásban (OTKA K-123847) kutatás támogatásával jött létre.

\title{
Bevezetés
}

Hinni a diplomában és tenni a bennmaradásért. A kettő egyértelmúen összefügg egymással. De lehetséges, hogy valaki úgy tesz a bennmaradásért, hogy nem hisz a diplomában? Vagy úgy hisz a diplomában, hogy nem tesz érte? Tanulmányunk végére választ kapunk ezekre a kérdésekre.

Abból a kutatási eredményből indulunk ki, amely arra mutatott rá, hogy a tanulmányok hasznosságába vetett hit és a tanulmányi bevonódás nem mindig a várt módon jár együtt (Ceglédi 2018). A HERD hallgatói kérdőíves kutatás egyik elemzésének középpontjában a reziliensígéretek álltak, akik kedvezőtlen társadalmi hátterük ellenére kimagasló eredményekkel léptek be a felsőoktatásba. Ezek a hallgatók voltak a legelszántabbak tanulmányaik befejezését illetően, viszont tanulmányaik hasznosságába vetett hitükre már nem volt igaz ugyanez. Olyasvalamiért mutattak lelkesedést, amiben nem hittek igazán (Ceglédi 2018). Mindebből annak a halvány jele bontakozott ki, hogy elválik az egyetemi lét manifeszt céljainak jelenben tapasztalható rituális követése a jövőbeli céloktól, ez esetben a diploma hasznosíthatóságától.

Tanulmányunkban annak járunk utána, hogy ez a kettősség vajon összefüggésben áll-e a lemorzsolódással. A nemzetközi trendeket követő magyar felsőoktatás kibocsátási oldalát nézve az látszik, hogy igen magas a lemorzsolódási ráta (Altbach 2010, Szabó A. 2012, Nyüsti 2013, 2014, Vukasovic és Sarrico 2010, Goastellec 2010, Hrubos 2012, Fehérvári és Misley 2016, Veroszta 2014, 2016a, 2016b, Fehérvári 2013, Szemerszki 2018, Pusztai 2018, Tóth 2018, Kozma 2004, Shavit et al. 2007, Benjamin 2015). A probléma jelentőségét mutatja, hogy a nemzetközi szakirodalom a felsőoktatáshoz való hozzáférésen túl megkülönböztető fogalmat használ a végzettséghez való hozzáférésre (access to degrees) (Goastellec 2010). 


\section{Kitartani cél nélkül? ${ }^{1}$}

Azzal kezdjük a válaszhoz vezető utat, hogy két lépést hátra lépünk a felsőoktatástól. E perspektíva fó kérdése, hogy a hallgatók életében mit jelentenek az egyetemi tanulmányok. Az intézményi nézőpont kifordítottjaként is értelmezhető ez a szemlélet. Nemcsak arra vagyunk kíváncsiak, hogy van-e életük a hallgatóknak az egyetemen kívül. Hanem megfordítjuk a kérdést: élnek-e az egyetemen, vagy egy elkülönült „buboréknak” látják az akadémiai életüket a hallgatók mindahhoz képest, amiben korábban éltek (Reay et al. 2009). Azaz: az egyetemnek a hallgatók életében milyen helye és szerepe van, s mire terjed ki egyrészt a jelenben, másrészt a teljes életútjuk időhorizontját nézve.

Milyen a hallgatók élete, életútja? Ha egy jelenbeli keresztmetszeti horizontra pillantunk, akkor a hallgatók életében az egyetemista lét csak egyféle tevékenység, és a hallgatói szerep csak egy a többi tevékenységeik és szerepeik mellett. Ha a teljes életút időhorizontján szemlélődünk, akkor egy-egy szak ma már egyre kevésbé egyértelmü belépő egy jól belátható karrier következő állomásába. A diplomásokat és hallgatókat vizsgáló szakirodalom egyre sokszínűbb egyéni életutakról beszél. A pályafutás kimenetei egyre kevésbé láthatók előre, az életszakaszok destandardizálódnak (Kohli 1990, idézi Bocsi 2013), az életút-állomások sorrendje individualizálódik, a korábban lineáris karrierek differenciálódnak (Pusztai 2009, Engler 2014, 2016, Sági 2013, Fehérvári 2015). Egy képzés például kevésbé jelentős állomást jelenthet egy-egy hallgató számára, mint ahogy az a klasszikus hallgatókép szerint volt. Akár az is előfordulhat, hogy az egyén szintjén olykor pozitívan értelmezhetők például a többféle terület megismerését támogató szak- vagy intézményváltások, más országban folytatott képzések, vagy akár az önfejlesztő munkával töltött passzív félévek (Szemerszki 2018, Sági 2013). Akár a szakhoz nem kötődő, egyetemi tanulmányok idejét nyújtó munkák is fejlesztő, elköteleződést növelö, kapcsolatépítő, célokat konkretizáló hatásúak lehetnek. Sőt, a lemorzsolódottak körében is kimutatható annak az előnye az egyéni életutat nézve (pl. tudatosabb fogyasztói- és egészségmagatartás), hogy valamennyi időt eltöltöttek a felsőoktatásban (Varga 1998). Mindezen mozgások az intézmény oldaláról lemorzsolódásként jelentkezhetnek, a folytonos képzés megtörései szervezési feladatokkal járnak. ${ }^{2}$

Összességében tehát az már önmagában egy sikertényező, ha a hallgató lát egy utat maga előtt, amelyben az egyetemet e célhoz vezető eszköznek tekinti. Az ideális az, ha a hallgatóévek alatt cél és eszköz együtt marad. Ugyanakkor ez a célkitüzés akkor is lehet sikeres, ha az egyetem menet közben nem váltja be a hozzá füzött reménye-

\footnotetext{
${ }^{1}$ A fejezet az alábbi könyv egyes részleteinek továbbdolgozott, a lemorzsolódás kérdéskörére adaptált változata: Ceglédi 2018

${ }^{2}$ Említést érdemel, bár vizsgálni nem áll módunkban a „lemorzsolódásnak” és a vele szembeni attitüdnek azt a fajtáját, amikor amiatt nem fejezik be tanulmányaikat egy-egy felkapott, piaci rést betöltő szak hallgatói, mert már a képzés alatt „elkelnek” a munkapiacon, és a rájuk zúduló hatalmas munkamennyiség miatt távolodnak el a diplomaszerzés céljától és halogatják a diplomamunkát és az államvizsgát. Ekkor a munka a diplomához képest „felfelé húzza” a karriert.
} 
ket (pl. nem ad megfelelö vagy annak érzékelt tudást), nem illeszkedik ebbe a tervbe. Ekkor az egyetem kudarcáról és nem a hallgatóéról beszélhetünk.

Hogyan válhat ketté a diploma hasznosságába vetett hit és a bennmaradásért mutatott erőfeszítés? A kérdést több szemszögböl is körbejárhatjuk. Kiindulhatunk a tanulás munkaként való felfogásának családi gyökereiből. Elsőként a család munkával és tanulmányi munkával kapcsolatos normáinak, értékeinek fontosságával, valamint ezek egymáshoz való viszonyával foglalkozunk. A tanulmányi munka komolyan vétele fakadhat kétféle családi útravalóból is. Egyrészt, amikor a családban egyértelmüen kettéválnak a szerepek, és a szülők feladata a munka, a gyermeké pedig a tanulás (Kozma 1975). ${ }^{3}$ Ekkor a munkához kapcsolódó mintákat, értékeket közvetve sajátítja el a gyermek, illetve szülei példáját saját tanulmányi munkájára adaptálva alkalmazza gyerekkorától kezdődően, a felnőtté válás gyakorlásának terepe a tanulás (Kozma 1975). Ahogyan a szülők dolgoznak, például alkalmazottként, ők úgy tanulnak, például tágabb célok nélkül, mert ez a feladata. Az elvégzendő feladat családi mintája lehet tehát az egyik olyan tényező, amely a tanulást függetleníti a céltól. Elképzelhető az is, hogy az egyetemet egy olyan ,munkahelynek tekintik”, ahol akkor kapnak „fizetést”, ha kiválóan végzik munkájukat, azaz a tanulást.

Ugyanakkor a megfelelő végzettség megszerzését a munkamegosztásban való részvétel feltételének tekinti, ahogy szülei is megszereztek egy adott végzettséget munkájuk elvégzéséhez (Kozma 1975). Valószínüleg főszereplőként van jelen ebben az esetben a gyermek, befektetett munkájával a saját jövőjét építi.

A tanulmányi munka családi gyökereinek egy másik formája, amikor a családban a gyermek elsődleges feladata, „munkája” a családhoz köthető (termelőmunka, házimunka), és a tanulás a második helyre szorul (Kozma 1975). ${ }^{4}$ Ekkor feltételezhetjük, hogy az így elsajátított, személyesen is megtapasztalt munkamorálnak valamilyen atipikus módon kell áttevődnie az oktatásban nyújtott teljesítményre, esetleg annak terhe mellett, hogy az ,első munkahelyen” is helyt állt a diák. Hagyományosan a családi (paraszti, később háztáji vagy kisipari) gazdaság állt a középpontban, napjainkban azonban annak szimbolikusan a háztartásra, otthonteremtésre, otthonszépítésre, otthonfejlesztésre, megélhetésre áttevődött megfelelője válik hangsúlyossá. Ebben „lecserélhető”, a gazdaságot mint közös családi célt szolgáló munkaerőként tekintenek az utódokra, nem a gazdaságtól erőforrást elvonó, karriert építő egyénre. Az is lehetséges, hogy a legtehetségesebb vagy legidősebb utód(ok) karrierje válik a közös céllá (a családi gazdaság helyett), és a családi erőforrások a karrierépítésben összpontosulnak - bár a régi minták szerint. Még tovább gondolva, elképzelhető, hogy az úgynevezett „tiszta szoba” jelenségét testesíti meg az az utód vagy azok az utódok, akiket taníttatnak. A tiszta szoba egy olyan, szinte érintetlen, a családi otthon környezetében első ránézésre valószerüt-

\footnotetext{
${ }^{3}$ Ahogy a szakmunkás - nem fizikai családokban ez tapasztalható volt egy hetvenes évekbeli interjús kutatás tapasztalatai szerint, s bár a társadalom hatalmas változásokon ment át azóta, a tanulás és munka ilyen módon történő összefonódása mai napig létező családi minta lehet (Kozma 1975).

${ }^{4}$ Ahogy ez például a homogén tsz-családok esetében tapasztalható volt az említett kutatás során megkérdezettek körében, akiknél a továbbtanulásra vonatkozó jövőtervekben legfeljebb a szakmaszerzés szerepel, érettségi már kevésbé (Kozma 1975).
} 
lennek tünő szoba, ahova az erőforrások összpontosulnak, szorgalmuk bizonyítékaként csinosítgatják, vendégfogadásra, tehát a külvilág felé történő reprezentálásra használják. Egy olyan „mikro világreprezentációt” építenek fel, amely vágyottnak is mondható, mégis esetlenül mozognak benne, mindennapi életüket távol tartják tőle. Ez az érinthetetlenség, a látszólagos funkciótlanság, a külvilág felé való reprezentálás, az erőforrások összpontosítása jellemző az atipikus módon taníttatott gyermekekre is. A „tiszta szoba szellemisége” és a vele járó felelősség pedig áttevődhet az iskolai viselkedésre: a fegyelmezettség, a rendkövetés formájában, vagy a jó jegyek reprezentációs szerepében, de akár a család mindennapi életéhez képest a másság kényelmetlen képviseleteként is.

A tudásfelhalmozás mint önmagában vett cél is okozhatja a fent említett jelenséget. Tehát nem egy papír, hanem már maga a tudás az a cél, ami miatt tanulnak, $\mathrm{s}$ ehhez nem szükséges, hogy higgyenek a diploma hasznosságában. Egy hetvenes évekbeli kutatás tanulsága szerint a szakmunkás-alkalmazott szülők esetében él az a nézet, hogy a tudást nem veszi el senki - (Kozma 1975). A múlt században megélt, tulajdont érő veszteségek ismeretében ez is indokolhatja a tudásfelhalmozást, például a tiszta szoba taníttatássá konvertálódása formájában.

A családon belüli nyitott vagy zárt szerepviszonyok is összefüggésben állhatnak a jelenséggel. Azok a hallgatók például, akik a családon belüli státusokhoz kötött, merev jogokhoz, kötelezettségekhez, elvárásokhoz szoktak, s a viselkedési normákat tekintélyelvi alapon, utasítások és kényszerek alapján sajátítják el (Bernstein 2003, Réger 2002), a hallgatói státushoz is merev jogokat, kötelezettségeket és elvárásokat társíthatnak, s a hozzá illeszkedő viselkedést kényszerek irányította tekintélyelvüség jellemezheti.

Az értékek oldaláról megközelítve a kérdést: Egy korábbi kutatásunkban, amikor jól teljesítő hátrányos helyzetủek interjúit elemeztük (Ceglédi 2012), az oktatásban jól hasznosítható értékekként tüntek fel az alacsonyabb státusúak körében egyébként is preferált fegyelmezettség, jó magaviselet, takarékosság, udvariasság (Bocsi et al. 2015). A magyar társadalomban élő történelmi hagyomány, hogy a szocializmus idején az előrejutás velejárója volt a többletmunka, a szabadidő eltörpülése (Fónai 1995, idézi Bocsi 2013). A szabadidő eltöltésére vonatkozó eljárásmódok ismeretének hiányában marad a munka, tanulók esetében a tanulás.

A diploma hasznosságába vetett hit és a bennmaradásért mutatott erőfeszítés széttartásának magyarázatai között az iskolai értékvilág elfogadását is számba vehetjük. A felsőoktatásba való bejutás egyik feltétele, hogy a hallgatók végig járják a megelőző iskolafokokat. Ehhez szinte elengedhetetlen, hogy a szülők és gyermekeik közeledjenek az iskola értékrendszeréhez. A család és az iskola nevelési elveinek harmóniája ugyanis ,az iskolai eredményességként hasznosuló társadalmi tőke egyik dimenziója” (Pusztai 2009: 167). A harmónia megteremtésében a szülő feladata egyrészt az, hogy megtalálja az ő értékvilágához legközelebb eső intézményt, másrészt igazodnia kell az iskolák évtizedes, sok szülő érdekeit szem előtt tartó hagyományaihoz (akár a saját korábbi értékei ellenében, akár azok finomítása által, akár egyetlen elem - pl. gyermeke továbbtanulásának segítése - alá rendelve egyéb nevelési értékeit) (Pusztai 2009). A gyermek sikere mint pozitív visszajelzés folyamatosan életben tartja, visszaigazolja az iskolák értékeinek és normáinak komolyan vételét, elfogadását és betartását. 
Egy az Arany János Tehetséggondozó Program tanulóit vizsgáló kutatásban az „iskolai mindenhatóságát" próbáltuk egy kísérleti kérdéssorral megragadni. Azt a kérdést jártuk körül, hogy a tanulók magukévá teszik-e az iskola céljait, eszközeit, öszszekapcsolódnak-e egyéni céljaik az iskoláéival, s hogy összességében mennyire hisznek az iskola mindenhatóságában vagy eleve hasznosságában. Felbukkant egy „értelemadás nélküli rituális” jelzővel ellátott típus, amely „értelemadás nélkül, monoton tagozódik be az iskola világába, közepes jelentőséget tulajdonítva a jövőorientált céloknak. Ezt a típust jellemzi leginkább, hogy az egész élete a tanulásról szól, hogy nagyon bántják a rossz jegyek, s a jegyek mindenhatóságába vetett hit is magas a körükben." (Hüse és Ceglédi 2018: 104). Ugyanakkor az olyan jelenorientált célok iránt elkötelezett, mint például az elismerés, amelyet tanulmányai munkájáért a diáktársaitól és szüleitől kap (Hüse és Ceglédi 2018).

Ez egybecseng egy roma tanulók körében végzett korábbi kutatással, amely tanulsága szerint jobban támogatják az iskolai motivációt a belső értékek (személyes növekedés, tartalmas kapcsolatok, társadalmi hasznosság), mint a külső értékek (gazdagság, hírnév és kinézet) vagy az egészség ${ }^{5}$ (Hüse 2015). Elképzelhető, hogy az iskolai intézményrendszerrel való azonosulás abból adódik, hogy komfortosan érzik magukat a jelenlegi közegükben. A hallgatók egy része a jelenorientáltság miatt még akkor is elfogadja az oktatás manifeszt célrendszerét, ha nem látja, vagy pillanatnyilag nem érzi fontosnak az azt követő boldogulást. Vagyis tanul a diploma hasznosságába vetett hit nélkül. Ebben mindemellett fontos szerepet játszhat akár a megélhetés jelenben érződő problémája, amelyhez a tanulmányi ösztöndíj segítséget nyújt, s amely hozzájárulhat egy komfortos hallgatólét fenntartásához.

Jelentheti mindez azt is, hogy az oktatást nem beruházásként „,használják”, hanem fogyasztási termékként (Varga 1998).

A hallgatói szocializáció is értelmezési keretként szolgálhat. A hallgatótársak felől érkező elvárásokat nehéz megítélni, ugyanis a töredezetté váló hallgatólétben (tömegkurzusok, változó sorrendben felvehető tárgyak, folyamatosan változó csoportösszetétel stb.) egyre kevesebb a lehetőség állandó hallgatócsoportok létrejöttére, s a lakótársak összetétele is átíródhat az évről-évre ismétlődő kollégiumi felvéte$\operatorname{lik}^{6}$ vagy a rövid távú albérleti szerződések miatt. A tanulással kapcsolatos hallgatói normák kialakulását így rendkívül nehéz megragadni, empirikusan tesztelhetővé tenni. A hallgatótársak tanulásról alkotott véleményének percepciója azonban minden bizonnyal fontos (Pusztai 2009). A hallgatótársak részéről a jó jegyekkel kivívott elismerés is hajtómotorja lehet a tanulmányi bevonódásnak. Ugyanígy az oktatók felől érkező elvárás (vagy vélt elvárás) is fontos, akik elismerését (vagy vélt elismerését) csak egy sikeres vizsga által nyerhetik el.

A felsőoktatás oldaláról szemlélve ugyanezt a jelenséget, az eltömegesedett oktatás maga hordozza az egyoldalú tanulásorientáltságot, hiszen a manifeszt elvárások engedelmes és gépies teljesítése (óralátogatás, vizsgára készülés, oktatóval való kapcsolat kerülése) annak kedvez, hogy gördülékenyebben müködhessen a

\footnotetext{
${ }^{5}$ Az Aspirációs Index Kérdőív magyar változatával mérve (Kasser és Ryan, 1993, idézi Hüse 2015).

${ }^{6}$ Lehetôség van a felvételi során annak jelzésére, hogy kik szeretnének együtt lakni, de ennek teljesítésében lehetnek esetlegességek.
} 
tömegoktatás szabványosított, elszemélytelenedett gépezete (Kozma 2004). Azáltal pedig, hogy a személyes kapcsolatok az illegalitás határát súrolják (akadémiai kockázatként is értelmezhetik oktató és hallgató közeledését) (Pusztai 2011, Kozma 2004, Bocsi 2016), a célok életre beszélése kiszorul az egyetemi hatáskörből. S ha az oktató beszélget is a diákkal céljairól, nem mindig gazdagíthatja növendékét az egyetemen túlmutató alternatívákkal, hiszen - ahogy egy interjús kutatásból tudjuk - az oktatók egy része nem lát vagy nem tekint az akadémiai látókörön kívülre (Bordás et al. 2011).

A munkavállaló idealisztikus képe is leképződhet a tanulmányokhoz mint munkához való hozzáállásban. Bernstein szerint míg a 19. század merev és alázatos embert kívánt, addig a 20. század második felében rugalmas, alkalmazkodó munkavállalókra van szükség (Bernstein 1996). Ugyanakkor a hallgatók kezdő munkavállalókként elsősorban alkalmazotti munkakört célozhatnak meg első ugródeszkaként, amelyben kívülről megszabott munkafeltételek várják, még ha nem is „,szellemi szalagmunka jellegü" munkát kíván választani.

Mit jelent mindez a hátrányos és nem hátrányos helyzetü hallgatók esetében? Hajlamosabbak a hátrányos helyzetüek elveszíteni hitüket a diplomában? Vagy épp ellenkezőleg: egyetlen kapaszkodóként tekintenek rá? A kritikusság, a rugalmasság megengedhető számukra?

A felsőoktatás egyenlőtlenségeit vizsgáló kutatások egyre nagyobb szelete foglalkozik a bekerülés tényén és minőségén túl a bennmaradás és a következő szint elvégzésének társadalmi meghatározottságával is (Altbach 2010, Vukasovic és Sarrico 2010, Polónyi 2018, Arató és Varga 2018, Alexeevna et al. 2017, Ceglédi 2018), s az Európai Felsőoktatási Térség találkozóin is szerepet kap a nem tradicionális csoportok segítése a végzettség megszerzésében (Széll 2016). A kedvezőtlenebb családi feltételekkel rendelkezők esetében a sikeres vizsgák letétele vagy a diploma megszerzése melletti kitartás pedig még nagyobb nehézséget okozhat (Vukasovic és Sarrico 2010, Bander 2014, Fehérvári 2015, Ceglédi 2015a, 2015b, 2018).

Korábbi kutatási eredményeink alapján elmondható, hogy a hátrányos helyzetü családokban is megtalálható a tanuláshoz füződő pozitív viszony, amely egy jól körülhatárolható, az oktatási rendszer elsődleges tanterveiben egyértelmúen deklarált elvárásrendszeren alapszik. A diák úgy tesz ennek a családi elvárásnak eleget, hogy a szülők felé látványosan „elkönyvelhető” tevékenységekben kimagaslóan teljesít, például jellemzőbb rá a szorgalmas óralátogatás, a jó jegyek vagy a sikeres vizsgák (Ceglédi 2012). A hátrányos helyzetű szülők ráadásul kevésbé tudnak különbséget tenni az egyes tantárgyak súlya között (Nagy P. 2010, Andor és Liskó 1999), a nem diplomás apák pedig fontosabbnak értékelik az órán való figyelést (Pusztai 2009). A felsőoktatás e manifeszt célrendszerével való azonosulás tehát feltételezésünk szerint - lehet a felsőoktatásba bejutott hátrányosabb helyzetü hallgatók családi hozománya.

A Kuh és munkatársai, valamint Astin által használt tanulmányi bevonódás a hallgatói létnek azt a dimenzióját leíró fogalom, amelyben a társadalmi törésvonalak is kiolvashatók. A tanulmányi bevonódás azt a pszichológiai és fizikai energiát és időt jelenti, amelyet a hallgató tanulmányi célú tevékenységébe fektet (idézi Koltói 2014, Pusztai 2011a). Bourdieu iskolai befektetésre való hajlamról beszél, amelyre befolyással bír az, hogy az adott személy osztálypozíciójának reprodukálása vagy 
javítása, társadalmi érvényesülése mennyire függ az intézményesült kulturális tőkétől, vagyis a diplomától (Bourdieu 1998, 2003a, 2003b). Kutatásunkban a tanulmányi bevonódás elemeinek tekintjük a tanulással és óralátogatással töltött időt és stratégiát, valamint az ezekkel szembeni attitüdöket.

Ha a felsőoktatás értékeivel való azonosulás a hallgatók egy részénél a diploma mint papír megszerzésére szükül le, s az ahhoz vezető lépésekben már meginog (távolságtartás az oktatókkal, alternatív hallgatói erkölcsi normák a leséssel, csalással kapcsolatban stb.), s valódi tartalommal való megtöltetlensége miatt a formális tartalmi jegyek (óralátogatás, jó jegyek) is csak azokkal tartathatók be, akik középiskolás mintákat és tapasztalatlanságon alapuló családi nyomást követve azonosulnak velük, akkor az ő esetükben valóban csak papírgyár (Polónyi és Timár 2001) az egyetem?

\section{A kutatás}

Elemzésünkhöz a "HERD: Higher Education for Social Cohesion - Cooperative Research and Development in a Cross-border Area" címú kutatási projekt keretében készült adatbázist használtuk. A papír kérdőívek instruktorral támogatott önkitöltése 2012 márciusa és júniusa között zajlott a következő intézmények hallgatói körében: Debreceni Egyetem, Nyíregyházi Föiskola Gazdasági és Társadalomtudományi Kar, Müszaki és Mezőgazdasági Kar, valamint Pedagógusképző Kar, Debreceni Református Hittudományi Egyetem Kölcsey Ferenc Református Tanítóképző Főiskolai Kar. A végleges mintaelemszám 1295 fö lett a felsorolt intézményekben. A kutatás célcsoportját a következő évfolyamok nappali tagozatos, állami és költségtérítéses hallgatói alkották: BA/BSc képzések 1. és 3. évfolyamai, MA/MSc képzések 1. évfolyamai, valamint az osztatlan képzések 1. és 4. évfolyamai. A mintavétel első lépésében az egyes karokon belül képzési szintenkénti és évfolyamonkénti rétegezést alkalmaztunk. Ezt követően adott kar adott rétegén belül véletlenszerüen kiválasztott hallgatócsoportokat kérdeztünk le teljes körủen (bővebben lásd: Györgyi és Nagy 2012).

\section{Elköteleződés típusok}

A diploma hasznosságába vetett hitre, a tanulás befejezése melletti elkötelezettségre, valamint a bennmaradásért mutatott erőfeszítésre vonatkozó válaszok alapján klaszterelemzést hajtottunk végre, amelynek eredményeként négy csoportot azonosítottunk (1. táblázat) ${ }^{7}$

\footnotetext{
${ }^{7}$ A változók klaszteranalízisbe való bevonása előtt ellenőriztük a klaszteranalízis feltételeit (a változók korrelációja 0,9 alatti, kiugró adatok nincsenek, nem valamelyik klaszterképző változó szerint voltak sorba rendezve az adatok). A mintaelemszám nagysága miatt a Kmeans klaszter eljárást választottuk.
} 


\begin{tabular}{|c|c|c|c|c|}
\hline $\begin{array}{c}\text { Milyen mértékben értesz } \\
\text { egyet... }\end{array}$ & $\begin{array}{c}\text { potyázók } \\
(\mathrm{n}=471)\end{array}$ & $\begin{array}{c}\text { rituális } \\
\text { perzisztensek } \\
(\mathrm{n}=202)\end{array}$ & $\begin{array}{c}\text { anómiások } \\
(\mathrm{n}=133)\end{array}$ & $\begin{array}{c}\text { célorientált } \\
\text { perzisztensek } \\
(\mathrm{N}=437)\end{array}$ \\
\hline $\begin{array}{c}\text { A tanulmányok, amelyeket } \\
\text { folytatok, hasznosak lesznek } \\
\text { számomra a szakmai karrie- } \\
\text { rem során }\end{array}$ & 3 & 2,75 & 2,36 & 3,78 \\
\hline $\begin{array}{c}\text { Nagyon elszánt vagyok a ta- } \\
\text { nulmányaim befejezését illetően }\end{array}$ & 3,18 & 3,76 & 2,24 & 3,94 \\
\hline $\begin{array}{c}\text { Szeretnék minél jobb tanulmá- } \\
\text { nyi eredményeket elérni }\end{array}$ & 3,1 & 3,79 & 2,38 & 3,87 \\
\hline $\begin{array}{c}\text { Mindent megteszek annak ér- } \\
\text { dekében, hogy részt vehessek } \\
\text { az elöadásokon, szemináriu- } \\
\text { mokon, gyakorlati órákon }\end{array}$ & 2,73 & 3,92 & 1,92 & 3,39 \\
\hline
\end{tabular}

Forrás: HERD 2012

1. táblázat. Elköteleződés típusok (klaszter középpontok) (négyfokú skála)

Szük csoportot alkotnak az anómiások $(n=133)$. Róluk mondható el legkevésbé, hogy hisznek tanulmányaik hasznosságában, és hogy erőfeszítéseket tesznek tanulmányaik sikerességéért. Ök érintkeznek legkevésbé az egyetem céljaival és elvárásaival. A potyázók $(n=471)$ amiatt érdekesek, mert alacsony erőfeszítéseik ellenére a második helyen állnak a tanulmányaik hasznosságába vetett hitben. Amiatt kapták a potyázók nevet, mert úgy gondolják, érdemes bent lenni, de inkább potyázva, mint aktív részvétellel: saját erőfeszítések tekintetében jelentősen elmaradnak a két perzisztens csoporttól, és (talán ebből következően) kevésbé is bíznak abban, hogy sikerül befejezniük tanulmányaikat. A másik végletet a két perzisztens csoport jelenti, akik két altípusra bomlanak. Az egyik egy célhoz rendeli tanulmányait, ezért kapta a célorientált perzisztens elnevezést $(n=437)$. Ez a cél a diploma, amiröl azt gondolja, hasznos lesz a számára. Ő a legelszántabb tanulmányai befejezését illetően, és ő törekszik leginkább jó tanulmányi eredményekre. A másik perzisztens csoport (a rituális perzisztensek) alig marad el ez előbbitől a tanulmányai befejezését illető elszántságban, a jó tanulmányi eredményekért való elkötelezettségben, sőt, a kurzusokon való részvételben még aktívabb is. Ugyanakkor nem hisz abban, hogy tanulmányai hasznosak a karrierje szempontjából. Aktivitása tehát inkább rituális, kötelességkövető, mindennapos tevékenységét egy intézményi szabályrendszernek rendeli alá. Merton (2002) kulturális célok és intézményes normákra vonatkozó típusalkotása alapján kapta a rituális jelzőt $(n=202)$. Elemzésünkből megtudhatjuk majd, hogy a rituális perzisztensek célnélkülisége vagy a potyázók erőfeszítés-nélkülisége jelent-e nagyobb veszélyt a lemorzsolódásban. 


\section{Az elköteleződés típusok társadalmi háttere}

Elsőként a típusok társadalmi hátterére voltunk kíváncsiak. Azt a kérdést jártuk körül, hogy a származás miképpen függ össze azzal, hogy a hallgatók a diplomához és egyetemi tanulmányaikhoz hogyan viszonyulnak. Észlelhető lesz a kedvező hátterüek anómiás vagy potyázó mivolta (Pusztai 2011, Veroszta 2010, Ceglédi 2018)? A kedvezőtlenebb hátterüek lesznek hajlamosabbak a rituális perzisztenciára?

\begin{tabular}{|c|c|c|c|c|c|c|c|}
\hline & & 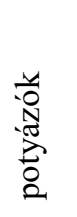 & 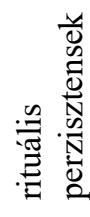 & 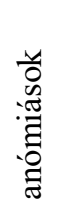 & 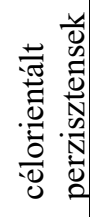 & 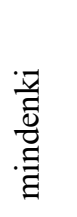 & 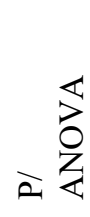 \\
\hline \multirow{2}{*}{ nem } & férfi & 34,1 & 22,7 & 43,9 & 29,1 & 31,4 & \multirow{2}{*}{0,000} \\
\hline & nő & 65,9 & 77,3 & 56,1 & 70,9 & 68,6 & \\
\hline \multirow{3}{*}{ apa iskolázottsága } & alap v. szakmunkás & 35,6 & 39,6 & 29 & 31,7 & 36,1 & \multirow{3}{*}{0,028} \\
\hline & érettségizett & 40,5 & 36 & 37,9 & 31,4 & 36,3 & \\
\hline & diplomás & 23,9 & 24,4 & 33,1 & 31,4 & 27,6 & \\
\hline \multirow[t]{2}{*}{ lakóhely } & $\begin{array}{l}\text { LHH vagy komplex } \\
\text { programmal célzott } \\
\text { LHH }\end{array}$ & 39,5 & 39,7 & 26,2 & 32,6 & 35,7 & \multirow[t]{2}{*}{0,022} \\
\hline & $\begin{array}{l}\text { csak hátrányos vagy } \\
\text { nem érintett }\end{array}$ & 60,5 & 60,3 & 73,8 & 67,4 & 64,3 & \\
\hline \multirow{3}{*}{ szülők objektív javai } & $0-1$ & 6,4 & 5,9 & 10,5 & 4,3 & 6 & \multirow{3}{*}{0,001} \\
\hline & $2-7$ & 83,4 & 90,6 & 75,2 & 87,6 & 85,2 & \\
\hline & $8-10$ & 10,2 & 3,5 & 14,3 & 8 & 8,8 & \\
\hline \multirow{2}{*}{$\begin{array}{l}\mathrm{HH} / \mathrm{HHH} \text { többlet- } \\
\text { pont felvételinél }\end{array}$} & kapott & 18,3 & 24,8 & 9,8 & 18,3 & 18,4 & \multirow{2}{*}{0,007} \\
\hline & nem kapott & 81,7 & 75,2 & 90,2 & 81,7 & 81,6 & \\
\hline \multirow[t]{2}{*}{ középiskola } & $\begin{array}{l}6 \text { vagy } 8 \text { oszt. és/vagy } \\
\text { két tannyelvü gimn. }\end{array}$ & 17,8 & 9,9 & 18,8 & 19,7 & 17,3 & \multirow[t]{2}{*}{0,021} \\
\hline & többi középisk. típus & 82,2 & 90,1 & 81,2 & 80,3 & 82,7 & \\
\hline \multirow{2}{*}{$\begin{array}{l}\text { szülői törődés fakto- } \\
\text { rai }\end{array}$} & általános & $\overline{-}, 05$ & 0,14 & $\overline{-}$ & 0,16 & 0 & 0,000 \\
\hline & értelmiségi & $\overline{-}, 07$ & $\overline{-}, 03$ & $\overline{-}, 05$ & 0,1 & 0 & 0,037 \\
\hline
\end{tabular}

Forrás: HERD 2012

2. táblázat. Az elköteleződés típusok társadalmi háttere (oszlopszázalék) ${ }^{8}$.

${ }^{8}$ A tanulmány minden táblázatában a félkövér azt jelenti, hogy kevesebb elem került az adott cellába, mint az véletlen elrendeződés esetén várható lett volna (Adjusted Standardized Residual $\leq-1,96$ ). A félkövér dőlt azt jelenti, hogy több elem került az adott cellába, mint az véletlen elrendeződés esetén várható lett volna (Adjusted Standardized Residual $\geq 1,96$ ) (Agresti 2002, Veroszta 2010). 
A négy csoport nemi eloszlása igazodik a gender kutatások korábbi eredményeihez (Fényes 2010), melyek szerint a nők szabálykövetőbbek. Felülreprezentáltak ugyanis a rituális perzisztens csoportban a női hallgatók, míg a férfiak inkább az anómiások táborát erősítik (2. táblázat). A családi háttér alábbi mutatói mentén nem különbözött szignifikánsan a négy csoport: anya iskolázottsága, krízisek a családban, településtípus, szubjektív anyagi helyzet. A táblázatban közölt háttérváltozók ugyanakkor összefüggtek a lemorzsolódásra való hajlam alapján felállított csoporttagsággal. A potyázók jellemzően a leghátrányosabb helyzetü kistérségek közepesen iskolázott családfővel rendelkező családjaiból érkeztek. Objektív anyagi helyzetük és hátrányos helyzetért járó többletpontjuk nem kiugró egyik irányba sem, és elit középiskolákból is átlagos arányban érkeztek. Az anómiások - akik a potyázókra alacsony erőfeszítéseikben hasonlítanak, de nem hisznek a diploma hasznosságában - ezzel szemben elönyösebb lakóhellyel bírnak, és alulreprezentáltak a HH/HHH többletpontok tekintetében. Érdekes ugyanakkor, hogy objektív anyagi helyzetük a két végleten helyezkedik el. Középiskolai útravalójuk átlagos. A két perzisztens csoport közül a célorientált perzisztens rendelkezik nagyobb arányban diplomás családfővel, míg rituális társaik közül többen kaptak $\mathrm{HH} / \mathrm{HHH}$ többletpontot és az elit középiskolák előnyeit is kevesebben élvezhették közülük. Hasonló a két csoport a lakóhelyet és az objektív anyagi helyzetet tekintve, bár ez utóbbi esetében a rituális perzisztensek felülreprezentáltak a közepes kategóriában.

Fontosnak tartottuk megvizsgálni a családon belüli társadalmi tőkét is. Faktorokat hoztunk létre a szülőkkel folytatott beszélgetésekre, programokra vonatkozó kérdéssor alapján. ${ }^{9}$ Az erre adott válaszok segítenek mélyebben értelmezni, hogy a négy csoport „durva” társadalmi ismérvein (szülök iskolázottsága, anyagi helyzet, lakóhely) túl mi jellemzi e családokat azokban a „szoft” tényezőkben, amelyek a diákok pályafutására hatással lehetnek. Különösen a lemorzsolódás magyarázatakor válhatnak fontossá az ilyen, kutatások által ritkábban vizsgált családi hozományok, hiszen az atipikus szülői hozzáállás akár felül is írhatja a társadalmi hovatartozás hatását (Blaskó 2002, Pusztai 2009, Ceglédi 2012, 2018). Ha egy alacsonyan iskolázott családban értékké válik a tanulás, az kihathat arra, ahogy a tanulmányi munkához és a diplomához viszonyulnak a hallgatók.

Az eredmények azt mutatják, hogy a perzisztens csoportokba kerülést valószínúsíti a magas általános szülői törődés, de egy fontos különbség van a két perzisztens csoport között. A célorientált perzisztensek több értelmiségi törődésben részesülnek, mint rituális társaik. Tehát fontosak az értelmiségi tartalmak a szülők törődésében a diploma hasznosságába vetett hit kialakulásával kapcsolatban.

Összességében elmondható, hogy a kedvezőtlenebb háttérből érkező rituális perzisztensek hajlamosabbak az intézményi elvárások rituális követésére, még akkor is, ha céljaikban bizonytalanok.

\footnotetext{
${ }^{9}$ Külön faktoron ülnek azok a beszélgetéstémák, amelyek az értelmiségi családokra jellemzők inkább: könyvekről, filmekről, kultúráról, politikai és közéleti témáról eszmecserét folytatni nem jelent mást, mint a kulturális tőkét közvetíteni, gyakorolni, inkorporálttá tenni a családon belül. Ez a faktor kapta az értelmiségi törődés nevet. A másik, általános törődés faktorában az olyan családi kötelékek összegződnek, mint a szabadidőről, tanulmányokról, barátokról való érdeklődés, a tanulásra való bátorítás (részletesebben lásd: Ceglédi 2018).
} 


\section{Hüség a felsőfokú tanulmányokhoz, az intézmény- hez, a szakhoz és a töretlen képzési életúthoz}

Kíváncsiak voltunk arra, hogy az egyes elköteleződés típusokhoz tartozó hallgatók hogyan nyilatkoznak saját lemorzsolódási veszélyeztetettségükről.

Nem meglepő, hogy kiugró a célorientált perzisztensek percepcionált védettsége a lemorzsolódástól (3. táblázat). Ök tartják legkevésbé valószínünek a felsorolt veszélyeket. Szintén látványos a másik véglet: az anómiások körében a legmagasabbak ezek az arányok, messze meghaladják társaikat veszélyeztetettségben minden téren. Érdekes, hogy nem a potyázók követik öket ebben. Egyedül abban bizonytalanok, hogy minden tantárgy sikerül nekik, de ez belefér potyázó lavírozásukba, mert egyébként minden másban az övék a második legvédettebb hely a célorientált perzisztensek után. Ez egyúttal azt is jelenti, hogy a rituális perzisztensek bizonytalanabbak egyetemi karrierjükben, holott elszántak a diploma - mint a felsőoktatás legkézzelfoghatóbb, manifeszt célja - megszerzése iránt, és ebbe energiát is hajlandók fektetni. Fontos tünet bukkant itt a felszínre: Akik nem hisznek diplomájuk hasznosságában, azoknak törékeny a kitartásuk, de leginkább hitük annak megszerzése mellett, és hajlamosabbak úgy érezni, hogy le fognak morzsolódni, mint a potyázók. Ha a potyázók diploma melletti kitartását az erőfeszítései alapján ítélnénk meg, részben torz képet kapnánk.

A rituális perzisztensek magukon viselhetik a korábbi oktatási szintek azon hatását, hogy a tanárok azokat tekintik tehetségesnek, eredményesnek, jó adottságúnak, akiket könnyebb tanítani, akikkel magas oktatási hatékonyságot érnek el (Kozma 1975). A tanárok általi elfogadás igénye általában fontos az iskolások körében (Pusztai 2009, 2011, Hüse 2015). Elképzelhető, hogy az ehhez a típushoz tartozó tanulók olyan áron nyerték el középiskolai oktatóik egy részének elismerését (és közvetve a továbbtanulást biztosító jó jegyeket), hogy leszoktak a kérdezésről, s helyette monoton módon követték tanáraik utasításait. Az iskolai szabályok kontrollja az énképük részévé válhatott, egyúttal komfortzónát alakítva, s fenyegetőnek érezhetik az ebből való kilépést, tartanak korábbi sikereik elvesztésétől. A jelenség összefüggésben állhat továbbá az alacsony önértékeléssel is. Az is lehet, hogy nincs bátorságuk saját célt megfogalmazni, ezért rituálisan elfogadják a felkínált célt (a diplomát). Objektív életkörülményeik is növelhetik bizonytalanságukat, hiszen azt láttuk, hogy kedvezőtlen családi háttérrel rendelkeznek.

Beszédes az az összevont adat, mely szerint minden negyedik hallgató úgy érzi, veszélyeztetett a lemorzsolódás valamely fajtájával. A tényleges lemorzsolódási adatokkal összevetve, még alá is becsülik ezt (Szemerszki 2018, Pusztai 2018). Figyelmet érdemel, hogy az anómiásoknál kumulálódva jelentkeznek ezek a problémák. 


\begin{tabular}{|c|c|c|c|c|c|c|}
\hline Mennyire valószínü, hogy... & 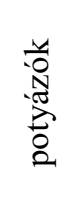 & 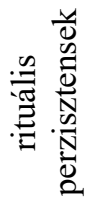 & 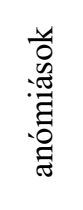 & 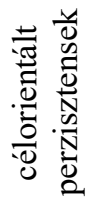 & 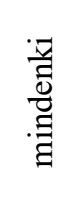 & $a$ \\
\hline $\begin{array}{l}\text { Abbahagyod a mostani tanulmányaidat } \\
\text { anélkül, hogy diplomát szereznél }\end{array}$ & 3,8 & 5,9 & 12,8 & 2,7 & 4,6 & 0,000 \\
\hline $\begin{array}{l}\text { Átiratkozol más egyetemre/föiskolára } \\
\text { ugyanebben az országban }\end{array}$ & 3,5 & 6,4 & 11,6 & 5,1 & 5,3 & 0,007 \\
\hline Legalább egy évet halasztasz & 8,9 & 11,2 & 17,9 & 6,1 & 9,1 & 0,001 \\
\hline $\begin{array}{l}\text { Szakot váltasz (anélkül, hogy befejez- } \\
\text { néd a mostanit) }\end{array}$ & 4,9 & 4,9 & 11,6 & 3,4 & 5 & 0,006 \\
\hline $\begin{array}{l}\text { Összevont veszélyeztetettség - leg- } \\
\text { alább eggyel veszélyeztetett az előző- } \\
\text { ekből }\end{array}$ & 24,7 & 24,7 & 49,2 & 20 & 25,6 & \multirow[t]{2}{*}{0,000} \\
\hline - semmivel nem veszélyeztetett & 75,3 & 75,3 & $\mathbf{5 0 , 8}$ & 80 & 74,4 & \\
\hline Néhány tantárgyat nem teljesítesz & 12,2 & 8 & 20,7 & 6,5 & 10,3 & 0,000 \\
\hline Egy félévet nem teljesítesz & 5 & 5,3 & 10,8 & 3,2 & 5 & 0,012 \\
\hline
\end{tabular}

Forrás: HERD 2012

3. táblázat. Az elköteleződés típusok veszélyeztetettsége a felsőfokú tanulmányok, az intézmény, a szak és a töretlen képzési életút tekintetében (valószínü és nagyon valószínü válaszok együtt) (oszlopszázalék).

\section{Összegzés}

Tanulmányunkban annak jártunk utána, hogy miképpen függnek össze a lemorzsolódáshoz kapcsolódó félelmek a diploma hasznosságába vetett hittel és az annak megszerzéséért nyújtott erőfeszítéssel. Elemzésünkhöz a "HERD: Higher Education for Social Cohesion - Cooperative Research and Development in a Crossborder Area" címü kutatási projekt keretében készült hallgatói adatbázist használtuk fel $(\mathrm{N}=1295)$.

A kutatás során felszínre került legfontosabb eredmény, hogy nem csak veszélyeztetettekről és perzisztensekről beszélhetünk. Olyan alcsoportokra bukkantunk, amelyek azt bizonyítják, hogy a lemorzsolódás nem egy lineáris skálán elhelyezhető jelenség. Legalább két dimenzió keresztbe metszi: a diploma hasznosságába vetett hit és a diplomáért történő erőfeszítés. E dimenziók bár összefüggnek, nem mindig egy irányba tartóan alakítják azt, ahogy a hallgatók tanulmányaikkal kapcsolatban gondolkodnak és cselekednek. 1) A rituális perzisztensek például magas erőfeszítésekre képesek, de nem hisznek a diplomában. Valami más hajtja öket: engedelmesség, komfortérzés, jelenorientáltság, félelem az addig befektetett energia elpazarlásától. 2) Mindez nem nyújt számukra akkora védelmet, mint a célorientált perzisztencia, vagyis az, ha valaki szorgalmához az is társul, hogy hisz a diploma hasznosságában. A célorientált perzisztensek érzik úgy a legkevésbé, hogy veszélyeztetettek a szakváltással, a felsőoktatás vagy az adott intézmény elhagyásával, 
illetve a halasztással. 3) A potyázó nevet kapó csoportot kisebb szorgalom jellemzi, de percepcionált védettségük nagyobb a rituális perzisztensekhez képest amiatt, hogy tudatában vannak a diploma értékének. A diploma hasznosságába vetett hit hiánya tehát rontja a hüséget a felsőoktatáshoz, adott intézményhez, szakhoz vagy a törésmentes továbbhaladáshoz. 4) Az anómiások fontolgatják lemagasabb arányban ugyanezeket. Ök a hallgatók kis hányadát teszik ki, de a legveszélyeztetettebb csoportként ők érdemelnek a legtöbb figyelmet.

A célnélküli szorgalom veszélyeket rejthet. Ez tanulmányunk összefoglaló megállapítása.

Kérdés, hogy hol van beavatkozási lehetőség. Ha abból indulunk ki, hogy mi az, ami megkülönbözteti a két perzisztens csoportot, akkor az erőfeszítésekre való képesség és hajlandóság tűnik egy fontos kulcsmozzanatnak. A potyázóknál ezt érdemes erősíteni. Ezen önmagában nem, vagy csak közvetve tudunk változtatni. A másik a diploma hasznosságába vetett hit, amely az anómiás és a rituális perzisztens csoportokban igényel támogatást. Ebben már megfoghatóbb lépések tehetők, amelyek visszahathatnak az erőfeszítésekre is. Az mindenesetre elengedhetetlen, hogy ne csak aktivitásra serkentsük a hallgatókat, hanem fontos a diploma értékének és a céloknak a folyamatos aktivizálása is.

A jövőben érdemesnek tartjuk körbejárni, hogy járhat-e előnnyel, ha valaki azon gondolkodik, hogy szakot vagy intézményt vált, esetleg halaszt, tehát kritikusan viszonyul tanulmányaihoz. A hallgatók erről alkotott véleményét vészjelként foghatjuk fel, vagy valójában a több lábon állás stratégiája, a rugalmasság, innovativitás olvasható ki ezekböl az adatokból? Hogyan lehet erre a jelenségre erőforrásként tekinteni? A beavatkozások szintjén érdemes lehet építeni a több lehetőséget keresők véleményére, tapasztalataira. Ötleteik gyakorlatba ültetése, saját kezdeményezéseik támogatása, véleményüknek a felsőoktatás egészébe történő visszacsatolása révén erősíthető a hallgatói perzisztencia.

\section{Hivatkozott irodalom}

1. Agresti, A. (2002). Categorical Data Analysis. New York: Wiley.

2. Alexeevna, A. M., Savitovna G.G. és Grigor' evich, K. V. (2017). Parents' education level and youth educational strategy. Hungarian Educational Research Journal, 7. 4:46-57, DOI:10.14413/HERJ/7/4/5

3. Altbach, P. G. (2010). Preface. Access Means Inequality. In Goastellec, G. (ed.). Understanding Inequalities in, through and by Higher Education. Rotterdam, Boston és Taipei: Sense Publishers. vii-x.

4. Andor M. és Liskó I. (1999). Iskolaválasztás és mobilitás. Budapest: Iskolakultúra.

5. Arató F. és Varga A. (2018). Befogadó egyetem. In Pusztai, G. és Szigeti F. (eds.) (2018). Lemorzsolódás és perzisztencia a felsőoktatásban. Debreceni Egyetemi Kiadó Debrecen University Press, Debrecen. (in press)

6. Bander K. (2014). A bekerüléstől a munkaerö-piaci beválásig - Átalakuló egyenlőtlenségek a felsőoktatásban. In Fehérvári A. és Tomasz G. (szerk.). 
Gondolatébresztők a felsőoktatás nemzetközi irodalmából. Budapest: Oktatáskutató és Fejlesztő Intézet. 65-74.

7. Benjamin, R. (2015). Leveling the Playing Field From College To Career. Council for Aid to Education.

8. Bernstein, B. (1996). Az iskolai tudásanyag osztályozásáról és kereteiről (framing). In Meleg Cs. (szerk.). Iskola és Társadalom. Pécs: JPTE Tanárképző Intézet Pedagógia Tanszéke. 78-94.

9. Bernstein, B. (2003). Nyelvi szocializáció és oktathatóság. In Meleg Cs. (szerk.). Iskola és társadalom. Budapest és Pécs: Dialóg Campus Kiadó. 173-197.

10. Blaskó Zs. (2002). Kulturális reprodukció vagy kulturális mobilitás? Szociológiai Szemle, 12. 2: 3-27.

11. Bocsi V. (2013). Az idő a kampuszokon. Szeged: Belvedere Meridionale.

12. Bocsi V. (2016). Eltérő kiindulópontok - azonos végpontok? Akadémiai integráció és eredményesség a településtípus függvényében. In Jancsák Cs. és Krémer A. (szerk.). Kisvárosi fiatalok, kisebbségek, új sebezhetőségek. Szeged: Belvedere Meridonale. 70-84.

13. Bocsi V., Morvai L. és Csokai A. (2015). "Jó szóval oktasd, játszani is engedd”. Pedagógusjelöltek gyermeknevelési értékeinek vizsgálata egy határmenti térségben. In Pusztai G. és Ceglédi T. (szerk.). Szakmai szocializáció a felsőoktatásban. Nagyvárad és Budapest: Partium, PPS és ÚMK. 253-266.

14. Bordás A., Ceglédi T., Németh N. V. és Szabó A. É. (2011). „Az egyetem embert képez, nem munkaerőt." - Diplomás pályakövetés oktatói szemmel. In Fónai M. és Szücs E. (szerk.). A Debreceni Egyetem „Diplomás Pályakövető Rendszerének" főbb eredményei és tapasztalatai 2010-2011. Debrecen: Debreceni Egyetem. 62-73.

15. Bourdieu, P. (1998). Gazdasági tőke, kulturális tőke, társadalmi tőke. In Lengyel Gy. és Szántó Z. (szerk.). Tőkefajták: A társadalmi és kulturális erőforrások szociológiája. Budapest: Aula Kiadó. 155-177.

16. Bourdieu, P. (2003a). Az oktatási rendszer ideologikus funkciója. In Meleg Cs. (szerk.). Iskola és társadalom. Budapest és Pécs: Dialóg Campus Kiadó. 10-24.

17. Bourdieu, P. (2003b). Vagyoni struktúrák és reprodukciós stratégiák. In Meleg Cs. (szerk.). Iskola és társadalom. Budapest és Pécs: Dialóg Campus Kiadó. 73-88.

18. Ceglédi T. (2012). Reziliens életutak, avagy a hátrányok ellenére sikeresen kibontakozó iskolai karrier. Szociológiai Szemle, 22. 2: 85-110.

19. Ceglédi T. (2015a). Resilient teacher education students. In Pusztai G. és Ceglédi T. (eds.). Professional calling in higher education. Nagyvárad és Budapest: Partium, PPS és Új Mandátum. 61-75.

20. Ceglédi T. (2015b). Felsőoktatás és társadalmi egyenlőtlenségek. Reziliens pedagógusjelöltek. In Pusztai G. és Ceglédi T. (szerk.). Szakmai szocializáció a felsőoktatásban. Nagyvárad és Budapest: Partium, PPS és ÚMK. 116-135.

21. Ceglédi T. (2018). Ugródeszkán. Reziliencia és társadalmi egyenlőtlenségek a felsőoktatásban. Debrecen: CHERD-Hungary.

22. Engler Á. (2014). Hallgatói Metszetek. Debrecen: CHERD-Hungary. 
23. Engler Á. (2016). A család mint erőforrás. A párkapcsolat és a gyermeknevelés szerepe a tanulmányi karrierútban. Habilitációs értekezés. Debrecen: Debreceni Egyetem.

24. Fényes H. (2010). A nemi sajátosságok különbségének vizsgálata az oktatásban. A nők hátrányainak felszámolódása? Debrecen: Debreceni Egyetemi Kiadó.

25. Fehérvári A. és Misley H. (2016). Hazai gyakorlatok. In Fehérvári A., Misley H., Széll K., Szemerszki M. és Veroszta Zs. (szerk.). A felsőoktatás szociális dimenziója. Hátrányos helyzetü csoportok hozzáférése és részvétele a felsőoktatásban. Budapest: Tempus Közalapítvány. 153-230.

26. Fehérvári A. (2015). Társadalmi mobilitás és az iskola. In Varga A. (szerk.). A nevelésszociológia alapjai. Pécs: Pécsi Tudományegyetem Bölcsészettudományi Kar Neveléstudományi Intézet Romológia és Nevelésszociológia Tanszék és Wlislocki Henrik Szakkollégium. 183-210.

27. Fehérvári, A. (2013). The Change of the Paths of Learning. Hungarian Educational Research Journal, 3(2), 1-11, DOI :10.14413/herj.2013.02.01.

28. Goastellec, G. (2010). Introduction. The Complex Issue of Inequalities in, Through and by Higher Education. In Goastellec, G. (ed.). Understanding Inequalities in, through and by Higher Education. Rotterdam, Boston \& Taipei: Sense Publishers. XI-XVI.

29. Györgyi, Z. és Nagy, Z. (2012): Empirical Survey. In Györgyi, Z. és Nagy, Z. (eds.). Students in a Cross-Border Region. Higher Education for Regional Social Cohesion. Oradea: University of Oradea Press. 13-15.

30. Hrubos I. (2012). A társadalmi esélyegyenlőtlenségek új színterei a felsőoktatásban. Iskolakultúra, 22. 1: 57-62.

31. Hüse L. (2015). Roma tanulók iskolai attitüdjeit befolyásoló tényezők. Szakkollégiumi Tudástár 1. ERSZK, Nyíregyháza.

32. Hüse L. és Ceglédi T. (2018): „Érett dió is lehetek.” A megterhelő életesemények és a reziliencia hatása az iskolai pályafutásra. Nyíregyháza: Evangélikus Roma Szakkollégium.

33. Kozma T. (1975). Hátrányos helyzet. Egy oktatásügyi probléma társadalmi vetületei. Budapest: Tankönyvkiadó.

34. Kozma T. (2004). Kié az egyetem? A felsőoktatás nevelésszociológiája. Budapest: ÚMK - Felsőoktatási Kutatóintézet.

35. Merton R. K. (2002). Társadalomelmélet és társadalmi struktúra. Budapest: Osiris.

36. Nagy P. T. (2010). Utak felfelé. Oktatás és társadalmi mobilitás a 19-20. századi Magyarországon. Budapest: Új Mandátum.

37. Nyüsti Sz. (2013). Oktatási helyzetkép. In Székely L. (szerk.). Magyar Ifjúság 2012. Budapest: Kutatópont. 90-126.

38. Nyüsti Sz. (2014). Nappali tagozatos hallgatók bevételeinek és időfelhasználásának egyenlőtlenségei. In A felsőoktatás szociális dimenziója. A Eurostudent V magyarországi eredményei. Budapest: Educatio Társadalmi Szolgáltató Nonprofit Kft. 39-52.

39. Polónyi I. és Timár J. (2001). Tudásgyár vagy papírgyár? Budapest: Új Mandátum. 
40. Polónyi I. (2018). A hátrányos helyzetü régiók felsőoktatási rekrutációjának néhány sajátossága. In Pusztai, G. és Szigeti F. (eds.) (2018). Lemorzsolódás és perzisztencia a felsőoktatásban. Debreceni Egyetemi Kiadó Debrecen University Press, Debrecen. (in press)

41. Pusztai G. (2009). A társadalmi tőke és az iskola. Budapest: Új Mandátum.

42. Pusztai G. (2018). Egy hatékony tényező a lemorzsolódás mérséklésére. In Pusztai, G. és Szigeti F. (szerk.) (2018). Lemorzsolódás és perzisztencia a felsőoktatásban. Debreceni Egyetemi Kiadó Debrecen University Press, Debrecen. 109127.

43. Reay, D., Crozier, G. \& Clayton, J. (2009). "Strangers in Paradise"? Workingclass Students in Elite Universities. Sociology, 43. 6: 1103-1121.

44. Réger Z. (2002). Utak a nyelvhez. Budapest: Soros Alapítvány és MTA Nyelvtudományi Intézet.

45. Sági M. (2013). Pályakezdő diplomások munkába állási stratégiái. In Garai O. és Veroszta Zs. (szerk.). Frissdiplomások 2011. Budapest: Educatio Társadalmi Szolgáltató Nonprofit Kft. Felsőoktatási Osztály. 111-142.

46. Shavit, Y, Arum, R., Gamoran, A. \& Menahem, G. (2007). (eds.). Stratification in Higher Education. A comparative study. Stanford, California: Stanford University Press.

47. Szabó A. (2012). A magyar egyetemisták és főiskolások társadalmi helyzete. In Szabó A. (szerk.). Racionálisan lázadó hallgatók 2012. Szeged: Belvedere Meridionale. 25-44.

48. Széll K. (2016). Külföldi támogatási gyakorlatok. In Fehérvári A., Misley H., Széll K., Szemerszki M. és Veroszta Zs. (szerk.). A felsőoktatás szociális dimenziója. Hátrányos helyzetủ csoportok hozzáférése és részvétele a felsőoktatásban. Budapest: Tempus Közalapítvány. 19-40.

49. Szemerszki M. (2018). Lemorzsolódási adatok és módszertani megfontolások. In Pusztai, G. és Szigeti F. (szerk.) (2018). Lemorzsolódás és perzisztencia a felsőoktatásban. Debreceni Egyetemi Kiadó Debrecen University Press, Debrecen. 15-27.

50. Tóth D. A. (2018). Elbukni a rajt után - Továbbtanulás és lemorzsolódás a Debreceni Egyetemen a képzési területek tükrében. In Pusztai, G. és Szigeti F. (szerk.) (2018). Lemorzsolódás és perzisztencia a felsőoktatásban. Debreceni Egyetemi Kiadó Debrecen University Press, Debrecen. 225-238.

51. Varga J. (1998). Oktatás-gazdaságtan. Budapest: Közgazdasági Szemle Alapítvány.

52. Veroszta Zs. (2010). Felsőoktatási értékek - hallgatói szemmel. A felsőoktatás küldetésére vonatkozó hallgatói értékstruktúrák feltárása (Ph.D. értekezés). Budapest: Budapesti Corvinus Egyetem.

53. Veroszta Zs. (2014). Kinek meddig tart a felsőoktatás? A tanulmányok alatti munkavállalás továbbtanulási tervekre gyakorolt hatása. In A felsőoktatás szociális dimenziója. A Eurostudent $\mathrm{V}$ magyarországi eredményei. Budapest: Educatio Társadalmi Szolgáltató Nonprofit Kft. 53-66.

54. Veroszta Zs. (2015). Frissdiplomások 2014. Budapest: Educatio Nonprofit Kht.

55. Veroszta Zs. (2016a). Frissdiplomások 2015. Budapest: Oktatási Hivatal Felsőoktatási Elemzési Főosztály. 
56. Veroszta Zs. (2016b). Hátrányos helyzetü hallgatói csoportok képzési életútja és munkaerő-piaci kilépése. In Fehérvári A., Misley H., Széll K., Szemerszki M. és Veroszta Zs. (szerk.). A felsőoktatás szociális dimenziója. Hátrányos helyzetű csoportok hozzáférése és részvétele a felsőoktatásban. Budapest: Tempus Közalapítvány. 119-152.

57. Vukasović, M. \& Sarrico, C. S. (2010). Inequality in Higher Education: Definitions, Measurements, Inferences. In Goastellec, G. (ed.). Understanding Inequalities in, through and by Higher Education. Rotterdam, Boston \& Taipei: Sense Publishers. XI-XVI. 